\title{
CLASS, HABITUS, AND THE DYNAMICS OF SOCIAL RELATIONS OF TRADERS IN DIAMOND TRADE IN THE MARTAPURA TOWN, SOUTH KALIMANTAN
}

\author{
YUSUF HIDAYAT ${ }^{1}$ \\ Universitas Lambung Mangkurat
}

\section{Abstract}

This study examines the pattern of social relationships among diamond traders in diamond trade that polarized into patterns of social relationships between small, medium and large traders with their respective values. This study aims to describe the pattern of social relationships between diamond traders and reveal the rules of the underlying game patterns of their social relationships that lead to polarization of social relationships between small, medium and large traders. This study used Buordieu framework especially about Field, Habitus, and Doxa to analyze the phenomena. This research uses qualitative research methods and has been implemented in the town of Martapura, South Kalimantan. In this study, five people were interviewed, consisting of merchants of a large trader, two medium traders and two merchants. The study finds that first, there are three forms of social relations pattern among traders of diamond namely: cooperation relationships between small traders, competition relationships between wholesalers and middle traders in accordance with its position, he develops cooperative relationships while in diamond market and relationships competition when trading outside the diamond market. Second, Each class has its own rules of play in accordance with their capacity in the sale and purchase of diamonds and the rules of this game have become a common consciousness among members of the merchant class so that all members of the group implement these rules spontaneously and without questioning its validity.

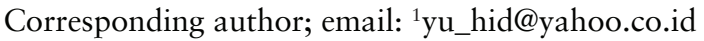


Penelitian ini mengkaji tentang pola hubungan sosial antar pedagang intan di dalam perdagangan intan yang terpolarisasi menjadi pola hubungan social antar pedagang kecil, menengah dan besar dengan nilainya masing-masing. Penelitian ini bertujuan untuk menggambarkan pola hubungan social antar pedagang intan dan mengungkap aturan-aturan main yang mendasari pola hubungan sosial mereka sehingga memunculkan polarisasi hubungan sosial antar pedagang kecil, menengah dan besar. Tujuan penelitian ini dianalisis dengan menggunakan kerangka pemikiran Buordieu terutama tentang Field, Habitus dan Doxa. Penelitian ini menggunakan metode penelitian kualitatif dan telah dilaksanakan di kota Martapura, Kalimantan Selatan. Dalam Peneltian ini, telah diwawancarai sebanyak lima orang informan yang terdiri dari pedagang seorang pedagang besar, dua orang pedagang menengah dan dua orang pedagang kecil. Penelitian ini menemukan bahwa pertama, ada tiga bentuk pola hubungan sosial antar pedagang intan yaitu: hubungan-hubungan kerjasama antar pedagang kecil, hubungan-hubungan persaingan antar pedagang besar dan pedagang menengah sesuai dengan posisinya, dia mengembangkan hubungan kerjasama ketika berada dalam pasar intan dan hubungan persaingan ketika bertransaksi di luar pasar intan. Kedua, Masing-masing kelas memliki aturan mainnya sendiri sesuai dengan kapasitas mereka dalam transaksi jual beli intan dan aturan main ini telah menjadi kesadaran bersama antar anggota kelas pedagang sehingga semua anggota kelompok melaksanakan aturan-aturan ini dengan spontan dan tanpa mempertanyakan lagi keabsahannya.

Keywords: diamond trader; doxa; habitus; social relations.

\section{Introduction}

Diamond trading is a dynamic trade because it is full of competition among diamond traders due to the limited availability of diamond commodities. However, despite the intense competition in the diamond trade, small traders still exist in the diamond trade and there are different social relations models among the traders class in diamond trading. There are two pat- 
terns of relationship between different diamond merchant that is the competition between large and small interpersonal partners. The two relationship models that appear in the diamond trade are interesting to examine because in a community that provides the same set of rules has led to the existence of two different relationship models so it is necessary to understand why those differences arise. Therefore, the study of the emergence of differences in understanding of the rules of togetherness in diamonds trading among large and small traders is important to study. Hopefully, with this study will be obtained a deep understanding of the differences in social relations patterns among diamond traders.

The study of the pattern of social relationships among diamond merchants is expected to add to the treasury in the study of traders that have been done by previous researchers such as the Evers (1994) study examining traders within the transitional society from agrarian to industrial society. They are faced with a dilemmatic situation when trying to connect between economic institutions, trade with social institutions of agrarian society (Evers 1994, 35).

Evers found five solutions of traders to get out of this dilemma: first, migration of minority traders by wandering to other areas and forming minority groups in people's areas; second, the formation of ethnic or religious groups; third, accumulation of honorific status (cultural capital) to improving self-image so that people can accept trading activities; fourth, the emergence of small traders with the characteristics of "there is no money"; fifth, depersonalization (inherent) economic relations (Evers 1994, 35).

Other studies on merchants are focused on the use of social capital for the development of merchant businesses. Abidin (2010) which examines the micro business entrepreneurs in PIK 
Pulo gadung who found that there is a relationship between social capital with the profit of SME traders in PIK Pulogadung. Social capital affects human capital (education) and physical capital in creating profit. These statistical findings indicate that social capital is an important aspect in the production of goods and services. Aspects of education, human capital and physical capital can be more optimal if the entrepreneur has also social capital. Social capital is more closely related to profit than physical capital and the contribution of social capital to profits is greater than the contribution of physical capital (Abidin 2010, 69).

Another study are conducted by Handoyo (2013) who examines the contribution of social capital to improving the welfare of street vendors. This study shows that the social network developed by street vendors, suspected of having functions that can be a foundation for their business continuity. There is an indirect contribution of social capital to the welfare of the street vendors. Social capital contributes to the welfare of street vendors, namely 'trust' among sellers of street vendors so that they can work safely, comfortably and comfortably in economic activities without any worries of the sellers of street vendors so that they can meet the needs of their families. In addition, social capital also contributes to social control through routine arisan activities. This activity has created a soothing condition for traders because of the atmosphere of togetherness (Handoyo 2013, 252).

In contrast to previous studies of traders as conducted by Abidin (2010) and Handoyo (2013) which further highlight the social capital aspect in trading success, this merchant study examines the pattern of social relations between traders in the transaction process in diamond trading. This study is almost similar to that of Evers (1994) which examines the traders' di- 
lemmas in agrarian societies, but this study sees the dilemma among diamond traders still within a diamond trading community. This study attempts to understand the dynamics of the pattern of social relations between traders in diamond trading as a form of implementation of the rules of the game (habitus) of each class so as to create stability in diamonds trading.

The existence of these differences must be important to understand the various forms of competition that occur both in small, medium and large diamond traders. For that, this research will explain how the forms of intan trader competition both between small, intermediate and large interpersonal capitalists? And what values are the basis for various forms of social relationships?

This research uses a conceptual framework developed by Bourdieu: Field, Habitus, and Doxa. The field is the realm of power partially autonomous and is also a field in which the struggles of positions take place. This struggle is seen as transforming or maintaining the realm of power (Bourdieu 1983, 12:12). Positions are determined by the division of special capital for actors located within the realm. When positions are reached, they can interact with the habitus, to produce different postures (positions) that have an effect on the 'positioning' economy within the realm.

The field is always defined by the objective system of power relation which exists between social positions corresponding to the objective system of relations that exist between the symbolic points: art, artistic manifesto, political declaration and so on. The structure of the realm is defined at a given moment by the balance between these points and between the divided capital. The field then identifies areas of struggle (Harker, Mahar, and Wilkes 2009, 10). Referring to Bourdieu's concept of fields, the diamond trade market is a field of diamond traders' struggle to dominate the diamond trading market. 
Traders trade in diamond markets based on the rules of the game designed to create stability in the process of trading in diamonds trading. These rules become their basis in the process of buying and selling that is tailored to the merchant classes occupied by each diamond trader. Each class has its own rules of game in the transaction process that aims to maintain the existence of all existing merchant classes in the diamond trading market. These rules within the conceptual framework of Bourdieu are known as Habitus.

Habitus is the systems of durable, transposable dispositions, structured structures predisposed to function as structuring structures that is, as principles of the generation and structuring of practices and representations which can be objectively "regulated" and "regular" without in any way being the product of obedience to rules, objectively adapted to their goals witout presupposing a conscious aiming at ends or an express mastery of the operations necessary to attain them and, being all this, collectively orchestrated without being the product of the orchestrating action of a conductor (Bourdieu 1995, 72).

Habitus is the result of a skill that becomes a practical action (not to be realized) which is then translated into an apparently natural and growing capability in a particular social environment (Haryatmoko 2003, 9-10). In the acquisition of the skill the structures formed are transformed into forming structures. Thus, habitus is a source of action, thought and representation.

According to Haryatmoko, the Habitus intended by Bourdieu is an interpretive framework for understanding and assessing the reality as well as producing life practices in accordance with objective structures. Habitus becomes the basis of individual personality. Establishment and functioning of the habitus such as the unknown circle of the tip of the hole. So there are two motions of reciprocity, the first objective structure which is 
fixed both subjective motions (perceptions, groupings, evaluations) that reveal the results of the bronze (Haryatmoko 2003, 9-10).

The next conceptual framework from Bourdieu is Doxa. Bourdieu introduces the word doxa which refers to the schemes of thought and perception produced by objective social structures, experienced by something natural and self-evident, that they are taken for granted. Doxa is made up of all the classification systems that set cognition boundaries as well as produce a misconception of the arbitrariness (the alterations) that underpin them (systems) (Haryatmoko 2003, 10).

Bourdieu's concept of Doxa is directed to the understanding that when the objective structure of a society is very stable and its mental structure is reproduced in its entirety, so that even though such structures are arbitrary, the alterations are unrecognized and misinterpreted as the right thing by itself (Bourdieu 1995, 164). This conformity between this objective and mental structure, in Bourdieu's view, is called doxa, since both 'orthodox' and heterodox have no meaning when there is no alternative consideration (Haryatmoko 2003, 13).

This research uses qualitative research methods to gain a deep understanding of the pattern of social relationships among diamond traders in diamond trading. With this method, researchers study objects in their natural context, which seeks to understand or interpret phenomena in terms of the meanings that humans (researchers) attach to them (Denzin and Lincoln $2009,2)$. The phenomenon examined by this qualitative method is directed at a detailed examination of the problems that arise naturally in social life (Neuman 2013, 189). Therefore, this study examines the pattern of social relationships between traders diamond in detail and deep so that can be obtained a deep understanding of the pattern of social relations. 
This research was conducted in Martapura town, Kalimantan Selatan. This town is used as a research location because of the following points: first, this town is one of diamond trading center in Indonesia. Secondly, Martapura town is a center of Banjar Regent whose area produces many diamond mining goods. Third, Martapura town is one of destination town for national and international diamond traders.

The subject of this research is the traders who are members of Martapura diamond trader community. The main sources of information in this study are diamond traders in accordance with their capacity. Informants as a source of information selected in this study determined by using purposive sampling technique that is selected informants based on certain considerations with the properties that can be known before. Based on these techniques, this study determines five traders as research informants. The number of informants is determined based on the adequacy of data, where at this amount of research data has started saturated. The five informants consisted of a large trader, two medium traders, two small traders.

The research data is obtained by three ways, namely: First, observation by directly observing the sale and purchase activities of diamond traders, how to greet the traders, the physical characteristics of the traders and various other behaviors related to diamond trading activities in diamond market in Martapura City.

Second, in-depth interviews by using guideline questionnaire to selected informants. Interviews with this model will give the informant more space to express what they think (Fontana and James H. 2009, 507). With this model, the authors are more able to explore what is thought and felt by the informant so that the author can more reveal the information from the informant's perspective and get the information from the informant. This 
interview was conducted from September to October of 2016. Each informant was interviewed in a varied time duration of 1-2 hours in accordance with the adequacy of data and assisted tape recorder as a recording device

Third, Diary is an important data source in the research used in this research. This diary is a field record of researchers who record what researchers, hear, see naturally and think about in the process of collecting data. This note allows researchers to absorb the data collection process and can reflect on what is happening. From the process of recording was obtained two notes, descriptive notes that presents a detailed event and not just a summary and reflective notes that present the mind framework, ideas, and attention of researchers.

The data can be obtained from the field in the form of recording interview and then transcribed. The interview transcripts were then given marginal notes of the theme studied, the sequence of events and the conceptual explanation of phrases written to facilitate analysis. Interview transcripts from several informants were then classified based on themes appropriate to the research objectives. The data has been classified and narrated so that it can describe the phenomenon in accordance with the data obtained from the field and generate various research findings. The findings were discussed with previous theories related to the research theme.

\section{Findings}

Rules of the Transaction Process in Diamond Trading

Diamond commodities are a scarce commodity and hunted by people because of their very high value. Therefore, diamond trade becomes very dynamic full of competition and intrigue among diamond traders. To maintain a stable state and remain in harmony develop the rules that promote the values of togeth- 
erness that developed in the diamond trade. The rules are developed with attention to aspects that need to be maintained in maintaining the integrity of diamond traders.

The rules of togetherness in the diamond trader community are deeply held. They should tell each other, share information and share opportunities with fellow diamond traders. The value of togetherness developed in the diamond trade is intended to create stability in the diamond trade so as to reduce the tension of competition among diamond traders is very high. So the phrases that arise among diamond merchants such as 'biarlah itu lobang inya' (let it be his plot), 'tidak enak hati' (disheartened), 'harus kongsi' (must cooperate), 'merahasiakan pembelian (conceal the purchase) are frequent expressions out of diamond merchants. All of the above phrases show how traders are guarding the importance of shared values in the diamond trade and are ingrained in their daily lives within the diamond trading community in Martapura.

In terms of the diamond trader relationship with the attachment, the value of togetherness is apparent when the trader gives opportunity to the giver to market their own diamonds. Traders of diamonds when asked 'why do not you just sell to other traders who need without going through intermediaries grazing? The answer is 'biarlah itu lobang inya' (Let it be his plot). The answer 'Let it be his plot' shows how diamond merchants give the other party the chance to play in the diamond trade. Because, if diamond traders do not give a chance to the 'pengempet' (intermediaries) then automatically the intermediaries will lose their work.

The granting of opportunity to the entrants to engage in diamond trade to be the intermediary of diamond sales shows how diamond merchants respect the values of togetherness among diamond merchants in accordance with their respective positions in the diamond trade. 
Another rule that appears in trading diamonds is that traders should not seize a potential buyer that has been faced by one of the diamond traders. This rule is the same as other commodity trading elsewhere. However, in the diamond trade, this rule becomes felt as a very human rule that arise from diamond traders who feel asa family in the diamond trader community. Therefore, when going to action to seize the buyer arises feelings of discomfort if betrayed his own friend. So the words that arise from diamond merchants to address this situation is the word 'nggak enak hati' as expressed by Taufik, one of the small traders in Martapura market. The phrase appears as a form of a sense of solidarity among those already awakened in an intimate intimacy between them in the diamond trading community.

Another form of the rule of togetherness in the diamond trade that when they live together in the diamond market, with his fellow traders then intends to buy diamonds then there is an obligation for him to invite his friend to share. This is an unwritten rule among diamond merchants. This is as disclosed by $\mathrm{Mr}$. Mawardi as follows:

"Amunnya kita ada di pasar nih sama-sama, terus ada orang yang menawarkan intan lawan kami, maka ulun wajib mengajak inya bakongsi. Itu adat kita lah."

("if we, the trader of diamond, live together in diamond market and coming for us the seller of diamond to offer diamonds to us we are obliged to invite them to joint venture. That is our rules.”)

According to him, that the merchant who found the offer of diamond and there are comrades beside him, then he must invite his friends to share even though he could actually buy the diamond itself. The necessity of inviting this partnership shows that merchants should maintain the value of togetherness among them. With an invitation to share means opening up oth- 
er friends who may have the same interest in the diamond, then to keep together, given the opportunity to to have it together. When the friend had the same courage at the same price as the merchant, then the partnership became the best choice for them. Unlike the case, when a friend who was offered refused to share and there is no similarity in the courage of the price because it is considered too high, he could walk alone without having to share with the friend earlier.

Some of the above rules are actually intended to maintain the existence of the traders, especially the small traders. Small traders who in their daily lives are so dependent on the market that they are subject to these rules. With their submission to these rules they can automatically keep their life alive. With this rule, traders do not kill off other traders whose lives are heavily dependent on the diamond trade.

The big traders, in other side, can survive even though they are not present in the diamond market so there is freedom for them to act according to their individual interests. Nevertheless, they do not penetrate small traders' merchants that are small diamonds but rather are directed at the large diamond hunting that becomes their slant.

\section{Rules of Togetherness and Individual Interests of Merchants}

The rules of togetherness that developed in the diamond trade are intended to maintain stability and harmony among diamond traders. So, for the survival of all diamond traders in the diamond market, they keep these values. On the other hand, however, merchants as free human beings perceive that the rules within the diamond trading community become their confinement in acting and transacting in the diamond trade. This condition creates a big dilemma for diamond traders in diamond trading. On the one hand it must follow the rules within the 
community of merchants they receive as a necessity for peaceful coexistence in the diamond trade, on the other hand, as a free man desires freedom in transactions of diamond trade in accordance with the interests of the individual them to get the diamond according to his will.

In addition, there is a dilemma for diamond merchants to maintain the values of togetherness for the sake of their trading activities, but on the other hand, as a trader, it is demanded to profit maximally by expending the ability to gain as much profit as possible achieve success in diamond trading.

Another dilemma that arises for diamond traders is that for the value of togetherness, diamond merchants are required to always cooperate with friends in the hunting of diamonds, but on the other hand, he wants complete diamond mastering so he has to compete with friends to get the diamonds. The dilemmas faced by diamond merchants will ultimately lead to various actions of merchants that seem to be ambiguous, but in fact they are the path they pursued as a form of compromise from the various dilemmas they face.

Their behavioral tendency to act toward the value of togetherness or individualistic value depends on how much capital they have and their position within the diamond trading structure. The size of the demands of the existing rules within the diamond trading community depends on their social position within the diamond trading community. For merchant groups such as small trader where they are in the lowest position, they do not have the ability to escape the demands, therefore they must follow the rules of the game in diamond trade. Unlike with small traders, middle boss, where he has more power than small traders in the form of material capital he has. With that position, he is more loose in the implementation of the demands of the rules of the game so as to enable to pursue their individual interests. Medi- 
um traders can get around the implementation of these binding attitudes by bringing some of their transactions outside the diamond market in addition to some being done in the diamond market to keep their position in the diamond market.

For large traders where they have social capital and cultural capital that qualified them to transact outside the diamond market that is in the places they want, including in their homes. They are autonomous traders in and can develop individualistic values that are not touched by the obligation of execution of "togetherness" values in the diamond trading market.

In other words, there is a difference in demand for the implementation of the rules among diamond merchants according to their capacity within the diamond trading community and in accordance with their degree of dependence on the diamond trader community. These differences have led to the polarization of competition models between large, medium and small traders.Thus, there is a polarizing model of competition between large, medium and small investors, all of which are closely related to their social position and their level of dependence on the diamond trader community.

\section{Polarization of competition Models of Large and Small Traders}

Community of Small Traders and the Harmony

Small traders every day come to the diamond market in the Martapura market from $1 \mathrm{pm}$ to $5 \mathrm{pm}$. They gather at two different locations under the 'mutiara' hotel located in front of the Martapura market for the rubbed) diamonds and in the middle of the Martapura market for raw diamond traders. In this location lined the stall used by diamond traders and the diamond polisher. In this market the traders who active to come there are collectors, small traders, broker and occasional medium traders. 
The process of buying and selling diamonds in the diamond market is different from the market in general where that happens is the process of buying and selling between traders with buyers as consumers, the diamond market that occurs is the process of buying and selling between the collectors who bring diamonds from the pendulangan (volk minning), the broker who sell diamond belonging to other traders (small traders and medium traders) and some times medium traders. Therefore, the process of buying and selling transactions that occur is felows diamond traders who eventually purchased diamonds in diamond market will be marketed to stores in CBS or buyers directly to the merchant or sold to other areas in Kalimantan and especially to Jakarta and overseas or sold to 'guests' from abroad who come to Martapura.

Their daily life in the diamond market, sitting together while chatting with coffee and cigarettes and other snacks. They joked while telling stories that they felt in everyday life both concerning himself, his neighbors, his friends and especially about their personal lives. They can complain about the problems of their lives.

In the midst of conversations and discussions that are engrossed they are talking about, some traders took out diamonds that he had then seen by his fellow traders to check the quality of diamonds, they pulled out a tool and then watched closely observer. They can take turns watching the item and the merchant asks: berapa ikam handak majual ini? (how much will you sell this?) The diamond owner then mentions some money for the price of the diamond. The merchant who had seen the diamond then showed the item to his fellow diamond traders. Then among the merchants negotiate who is interested to have the diamond and if only one who is interested, the bargaining continues to be done by the trader with the diamond owner. But 
if many traders are interested they could have the diamonds simultaneously by join venture.

During the process of weighing the quality of the diamonds, the first trader holding the diamonds was given the opportunity to extract the diamond with a long duration for a quarter of an hour he weighed the diamonds if necessary they carried the diamond to a quiet place to concentrate. When the merchant is in the process of observing no merchant can interrupt or ask him to hurry. If they are there, wait for the merchant to finish observing the diamond. "Itu adat kita, membiarakan kekawanan mengamati dengan tenang kadada nang mengaganggu” (It is our custom, let the caliphs observe it quietly in an annoying way) Said Taufik, one of the small traders, explained to the author.

In addition to such a model, there is also a trader who wants to sell diamonds to one of the other merchants to offer diamonds then they both come out of the crowd and immediately see their diamond then the diamond trader observes and fights price match if there is agreement. If they did not match the price the diamond owner will go to another merchant. The transaction process runs daily in the diamond market.

The transaction process in the diamond trade in Martapura diamond market is no noise where all traders respect the rights and obligations of each trader so that the diamond trade runs smoothly. They keep the togetherness they fertilize in the diamond trader community. They keep each other diamond traders because they really need and depend on the community so that they can exist in the diamond trade.

\section{Middle Trader: Between Harmony and Individualism}

In the midst of the preoccupations of small traders discussing something about their lives, a trader suddenly appears to 
wear muslim shirt or a right-arm shirt and uses a 'Haji' cap. $\mathrm{He}$ is a middle trader who occasionally comes to the diamond market. They usually come rather late than the small traders usually come to the diamond market around $14: 00$ or $15: 00$ to $17: 00$ hours or sometimes also go home earlier than the small traders and broker.

The position of middle traders usually gathered behind CBS (Cahaya Bumi Selamat) shopping center shops craft and precious stones in Martapura, near car parking. The location where they gather is relatively greater and cleaner than the small diamond traders hanging out. They usually gather in this place, but certain hours sometimes look to the small traders community in the Martapura market.

When a middle trader arrives at a small trader's place he is surrounded by small traders to simply greet him while offering a medium-size diamond they have. In the process of interaction with small traders, middle traders always maintain the attitude and dignity as diamond boss. They are the ones who are respected among diamond merchants. Muslim shirts and wearing 'hajji caps' are their distinctions from small traders. Using these attributes actually to show 'distinguishing' between them and the small traders.

The number of middle traders just twelve people. They respected each other as fellow diamond traders. The intensity of their meetings is not as frequent as small traders since their presence in the diamond market is not necessarily daily so that among them is not necessarily met, it could be that in a week they do not meet at all due to the disagreement of their arrival time in the diamond market. Their emotional relationship, therefore, is not so much as diamond merchants because the social distance formed by itself bears the title of the intermediate trader plus the intensity of their rare encounters. 
Under this condition, middle traders are more individualistic than small traders, they are more self-transacting than coinciding with other traders. However, when they are together and there are traders of diamonds that offer diamonds, they must provide other opportunities to join venture.

In the process of diamond transactions, more and more intermediate traders determine the price of diamonds because they are considered to be the most expert in measuring diamonds. In contrast to the small diamond traders community, where the process of diamond transactions applies to a very fierce bargaining process among diamond traders, here, as they are positioned as an expert to assess, the more middle traders determine the price of the diamond, no matter how much he mention them follow.

In the process of buying and selling diamonds among middle diamond traders do not seem to compete with each other. They let when a diamond merchant or giver offers a diamond to one of the middle traders, just as in a small diamond trader community, there is an unwritten rule that they must let the first trader look carefully at the diamond being bargained. When it's not over, they can even bring it home to check on their home. When at the point where diamond transactions can conclude about the price of the diamond, they will offer to other middle diamond traders who are there to join the diamond view. They will say: “ini ji ada barang bagus, kaya apa pian handaklah?" (haji ${ }^{2}$ this is a good diamond, are You interested?) Usually the middle trader sees the diamond and weighs the first trader even though he has a desire to own the diamond, he should offer the diamond to a middle-class merchant.

In a mutual position, the middle trader, according to the unwritten rules of the diamond trade, must give traders nearby to

\footnotetext{
${ }^{2}$ A call to the fellow diamond traders who are both pilgrims.
} 
jointly own the offered diamonds. The difference is that if the diamond merchant does not dare to bid the first trader, because it is considered too high price above his estimates, then he voluntarily provide the opportunity to have diamonds to the highest estimate.

In addition to transactions within the diamond market, these intermediate traders often also trade diamonds outside the diamond market, especially in their homes or elsewhere in accordance with the agreement. This is done by diamond traders to more freely in doing bargaining in getting diamonds. Because, by transacting outside the diamond market, the obligation to conduct the counseling can be avoided so that he can freely master the diamond completely according to their tastes. Different if the transaction in the diamond market, they must first share with fellow diamond traders.

Although they often do diamond transactions outside the diamond market, but the possibility to get a diamond does not always come to the house, still he must find his own diamond seller who will sell the diamond. And that is in the market. Therefore, the position of middle diamond traders is in the middle position between life in the diamond market and outside diamonds where when in diamond market, it must submit to the rules of togetherness created in the diamond market and can develop their individual desire by doing diamond transactions outside the diamond market.Thus, the competition model among middle traders is in the middle model between harmony and individualism.

\section{Trully Competition between Large Traders}

Large traders usually have other business beside as a diamond merchant. There are those who work as a contractor, control the mines and have some shops that sell any public needs, etc. They are highly respected people in the diamond trade. They 
will dump their capital to buy diamonds when found a truly large diamond above 50 million to hundreds of millions even for several cases up to billions of rupiah.

Their daily lives are rare and can even be said to never come to the diamond market. They do more diamond transactions in their homes or on-site in accordance with the agreement between the diamond seller and the wholesaler.Given the large number of diamonds rarely found, then when there is information about the discovery of a large diamond, the competition to get this diamond becomes very thick. The large traders will fight it out to get this diamond. Because by obtaining these diamonds, the possibility of profiteering is huge. For that, they tried to get it.

For large diamonds, diamond owners have never brought the diamond to the diamond market but directly faced with large investors, can the diamond owner coming to a diamond trader or otherwise a big diamond trader, usually through his representative, who directly meets the diamond owner in their house.

In this diamond hunt, tricks and intrigues are done by traders to get this great diamond. But, in the practice of this hunting diamond, the big trader is not alone he must use their group to get the diamond from start chasing until getting the diamond. Therefore, the wholesaler desperately needs a subordinate who will help him to get the diamonds and that he gets in a partnership deal with the middle trader.

Their group will work from the moment they start looking for information about the whereabouts of diamonds. Because of the positions of the large trader who did not interact with small traders and with the miners, they need the information supplied by the middle traders who are their subordinates. For that reason, it has important for large diamond traders in winning the battle for diamonds. 
Thus it appears that the competition between large traders is very thick traders have not taken into account the harmony again but more to the competition to get the diamond. To justify this competition, the merchants unleash all the moves and powers to pit against the diamonds. However, the competition process by these large diamond traders will not work without the support of a group of people who are part of the group in a partnership. Without support, large diamond traders will not be able to win the diamond hunting competition because of how fierce the fighting is.

\section{Discussion}

The polarization of social relationships between small traders, medium and large with a set of rules of common play for each class of traders can be understood by two sets of concepts developed by Pierre Bourdieu the field and habitus. These crucial concepts are supported by a number of other ideas, such as symbolic power, strategy, and struggle (symbolic and material power), along with various types of capital (economic, cultural and symbolic capital).

The concept of the 'field' used by Bourdieu is seen as a dynamic 'sphere of power', in which multiple potentials exist. This conception is compared with the 'frame', the rules of irrelevance, and so on from Goffman. However, Bourdieu is different from Goffman in which for Bourdieu, structural properties are always stored in everyday events while for Goffman, these structures are a distant echo. Therefore, the field is the realm of power partially autonomous and is also a field in which the struggles of positions take place. This struggle is seen as transforming or maintaining the realm of power (Bourdieu 1983, 12:12)

Positions are determined by the division of special capital for actors located within the field. When positions are reached, 
they can interact with the habitus, to produce different postures (positions) that have an effect on the 'positioning' economy within the field.

The field is always defined by the objective system of power relation which exists between social positions corresponding to the objective system of relations that exist between the symbolic points: art, artistic manifesto, political declaration, and so on. The structure of the field is defined at a given moment by the balance between these points and between the divided capital. The field then identifies areas of struggle (Harker, Mahar, and Wilkes 2009, 10).

Referring to Bourdieu's concept of field, the diamond trade market is a field of struggle between traders. The market as an environment sees that the market is a battleground. It is a kind of competition market where various types of capital (economic, cultural, social and symbolic) are used and disseminated. The position of the various agents in the environment is determined by the amount and the relative weight of the capital they have. For Bordieu, capital allows people to control their own destiny and the fate of others. Occupants of positions within the environment seek individually or collectively to protect and/or enhance their position and seek to impose the most favorable profitability principles on their own products. The agent's strategy depends on their position in the environment.

The competition in obtaining diamond commodity depending on the ownership of capital. Economic capital in the form of material possessions, social capital in the form of ownership of social networks on diamond trading and cultural capital which is the ownership of knowledge in estimating the price and quality of diamonds and symbolic capital in the form of prestige of someone who is usually a person's position in the diamond trade social structure. Based on the accumulation of the ownership of 
capital (economic, social, culture and symbolic) the traders have divided into three classes of diamond traders: small, medium and large traders.

Each class in the diamonds trading process has its own different rules of play according to their attachment to the market situation. Small traders who are not biased from the diamond market situation they develop the values of togetherness and vice versa large traders who have a large degree of autonomy is not bound by the diamond market situation they develop the values of competition. In other words, social class differences have led to a series of rules (dispositions) for members of the class in making transactions buying diamonds. These dispositions are known in Bourdieu's thought as 'habitus'.

Pierre Bourdieu defines habitus as a durable, transposable disposition system that serves as a generative basis for objectively structured and integrated practices (Harker, Mahar, and Wilkes 2009, 13). The result of a habitus is the time-sustaining and inherited disposition systems, the structures formed, which are meant to function as structures that constitute, that is to be the driving principle and regulator of living practices and representations, objectives without presupposing the purposeful direction and intentional mastery of the efforts necessary to achieve them, objectively organized and organized without necessarily being the fruit of obedience to the rules and collectively harmonized without being the result of the conducting arrangement (Haryatmoko 2003, 9-10).

Habitus in the diamond trade field can be the rules held by diamond traders when interacting with fellow diamond traders in the diamond trader community. The habitus of each diamond merchant group can be the rules that apply to the group and become their reference in interacting with their fellow. For small traders and granaries, for example, the rules that frames them 
when interacting with others are in the form of values and rules of cooperation and togetherness. These values are held firmly by the merchants and make it a reference in action and they will spontaneously act in a framework of cooperation and togetherness. The rules of togetherness for small traders serve to maintain their existence because if the rule were not developed of course they will run out along with the increasing scarcity of diamonds that they peddle. Another case with a large trader, the values that grow in this group are the values of competition that all the large traders will act according to this rule and they will do it spontaneously. While the middle trader (boss) develops the values of both.

The rules of games in diamond trade have grown and developed over a long period of time and have become the basis for trade practices by diamond traders so that diamond traders implement these rules automatically and no longer question the truth of this rule because they regard it as naturally born rules that they must obey. They execute this rule spontaneously and consider it a fairness to obey it. It is at this point that the practice of trading diamond traders using the rules of the game is known in Bourdieu's thought as a Doxa. Bourdieu's concept of Doxa is directed to the understanding that when the objective structure of a society is very stable and its mental structure is reproduced in its entirety, so that even though such structures are arbitrary, the alterations are unrecognized and misinterpreted as the right thing by itself (Bourdieu 1995, 164; Bourdieu 1991).

As a doxa, the rule of trade in diamonds that governs diamond merchants is the rule of togetherness for small traders and the competition for wholesalers and between these two rules for middle traders has been adhered to by diamond merchants spontaneously and without questioning the truth. This doxa in Bourdieu's view is usually made to reinforce the position of the 
dominant classes. But in diamond trading, the rules of games in diamond trade in diamond commodities are very rare precisely made to protect small traders to remain involved in trading diamond amid their limitations materially. These rules were precisely designed to fortify them from their market-ruling efforts by the wholesalers. In other words, doxa by diamond traders is not always made to reinforce the position of powerful people by weakening the weak, but also (as in the practice of diamonds in Martapura city), to protect weak traders. This doxa runs and is preserved precisely to maintain the continuity of diamond trade amid the scarcity and and the high price of diamond commodities in the world market.

\section{Conclusion}

The diamond traders in Martapura town are divided into three classes of traders: small, middle and large traders based on their capital (economic, social, cultural and symbolic) accumulation. These merchant classes when interacting with the same class traders have their own rules governing them in the process of buying and selling diamonds.

The rules of play in the process of trading diamonds created to create a relationship of harmony and togetherness in the process of buying and selling diamonds. These rules are necessary to maintain the stability and existence of diamond trade aimed the scarcity and high prices of these commodities.

These rules are made for the process of buying and selling diamonds in the diamond market so that the more traders bound to the diamond market the greater their obligation to maintain these values of togetherness and harmony. Implementation of these values is also related to the empowerment of diamond traders so that more traders are bound by the diamond market because of their helplessness the more they are obliged to carry out these cooperation values. 
This condition led to the polarization of the pattern of social relations between traders in trading diamonds, namely: the relationships of cooperation between small traders who daily transact in the diamond market and the relationship of competition among wholesalers who often transact diamonds outside the diamond market. While the middle trader is in line with his position, he develops cooperative relationships while in the diamond market and the competition relationship when trading outside the diamond market.

These rule of games have become a habitus of the merchant class so that it becomes the doxa that they carry out these rules of the game spontaneously.

\section{Bibliography}

Abidin, Djainal. 2010. "Modal Sosial Dan Dinamika Usaha Mikro Kecil.” Jurnal Sosiologi Masyarakat 15 (1): 69-85. doi:doi/org/10.7454/mjs.v15i1.3708.

Bourdieu, Pierre. 1983. The Field of Cultural Production, or: The Economic World Reversed. Poetics. Vol. 12. doi:10.1016/0304-422X(83)90012-8.

- 1991. Language and Symbolic Power. Cambridge: Harvard University Press.

. 1995. Outline of a Theory of Practice. Grear Britain: Cambridge University Press.

Denzin, Norman K., and Yvonna S. Lincoln. 2009. Handbook of Qualitative Research. Yogyakarta: Pustaka Pelajar.

Evers, Hans-Dieter. 1994. “The Trader Dilemma: A Theory of Social Tarnsformation of Market and Society." In The Moral Economy of Trade : Ethnicity and Developing Markets, edited by Hans-Dieter Evers and Heiko Schrader. London: Routledge. 
Fontana, Andrea, and Frey James H. 2009. “Interview Art.” In Handbook of Qualitative Research, edited by Norman K. Denzin and Yvonna S. Lincoln. Yogyakarta: Pustaka Pelajar.

Handoyo, Eko. 2013. “Kontribusi Modal Sosial Dalam Meningkatkan Kesejahteraan Pedagang Kaki Lima Pasca Relokasi." Komunitas: International Journal of Indonesian Society and Culture 5 (2). doi:10.15294/komunitas.v5i2.2743.

Harker, Richard, Cheelen Mahar, and Chris Wilkes. 2009. (Habitus $x$ Modal + Ranah = Praktik: Pengantar Paling Komprehensif Kepada Pemikiran Pierre Bordieu. Yogyakarta: Jalasutra.

Haryatmoko. 2003. "Menyingkap Kepalsuan Budaya Penguasa: Landasan Teoritis Gerakan Sosial Menurut Pierre Bourdieu." Basis.

Neuman, W. Lawrence. 2013. Social Research Methods Qualitative and Quantitative Approaches. Jakarta: Index. 
This page intentionally left blank 